U. S. DEPARTMENT OF HEALTH, EDUCATION AND WELFARE NATIONAL INSTITUTE FOR OCCUPATIONAL SAFETY AND HEALTH

Cincinnati, Ohio 45202

HEALTH HAZARD EVALUATION DETERMINATION

Report No. $75-84-235$

INSTANT COPY SERVICE

Philadelphia, Pennsylvania

NOVEMBER 1975

I Toxicity Determination

It has been determined that employee exposure to acetic acid and hydroquinone mist during the film developing and fixing operation was not excessive at the concentrations measured on July 31, 1975. This determination is based on the analysis of airborne samples, observation of the work practices and non-directed medical questionnaires.

At the time the request was initiated, therewas a breakdown in the air movement system. This was subsequently repaired following the initial visit on April 30, 1975.

Information concerning environmental results are contained in the body of the report.

I Distribution and Availability of Determination Report

Copies of this Determination Report are available upon request from the Hazard Evaluation Services Branch, NIOSH, U. S. Post Office Building, Room 505, 5th \& Walnut Streets, Cincinnati, Ohio 45202 .

Copies have been sent to:

a) Instant Copy Service

b) Authorized Representative of Employees

c) U. S. Department of Labor, Region III

d) NIOSH - Region III

For the purpose of informing the 2 "affected employees" the employer will promptly "post" the Determination Report in a prominent place(s) near where affected employees work for a period of 30 calendar days.

\title{
II Introduction
}

Section 20(a)(6) of Occupational Safety and Health Act of 1970,29 U. S. Code $669(a)(6)$ authorized the Secretary of Health, Education and Welfare, following a written request by any employer or authorized representative of employees, 
2 (cont') $75-84$

to determine whether any substance normally found in the place of employment has potentially toxic effects in such concentrations as used or found.

A health hazard request was submitted by an employee representative of the Instant Copy Service. The request was submitted alleging irritation from the contaminants due to the breakdown of the air movement system.

IV Health Hazard Evaluation

A. Description of Process - Conditions of Use

Instant Copy Service reproduces printed matter. The operation of interest was the film developing room. Pictures of printed matter are reduced, cut out or retouched. Photographs of these pictures are then taken and developed. The film is first subjected to a developer, which contains hydroquinone, and then to a fix bath, which contains acetic acid. other chemicals are present in these baths, such as boric acid, potassium chloride, sodium bromide and thiosulfates; however, the toxicity of these materials is minimal. Following the developing, the photographs are hung on a line and air-dried.

The developing operation is done in a darkroom approximately 8 x 15 feet with a 10-foot ceiling. Exhaust ventilation is supplied by a 6-inch fan. Operations in the darkroom are intermittant depending on the workload. Prior to the atmospheric evaluation, another tenant of the building also utilized this room. This tenant has since moved.

\section{B. Study Progress and Design}

On April 30, 1975, an initial survey at the site was conducted by Walter Chrostek, industrial hygienist. A walk-through survey and non-directed medical questionnaires were completed.

Subsequently, an atmospheric evaluation to determine if the employees were exposed to acetic acid and hydroquinone mist was done on July 31, 1975.

C. Evaluation Methods

operator's exposure to acetic acid and hydroquinone mist was evaluated utilizing midget impingers with distilled water as collection media and personal air sampling pumps. Samples for acetic acid were analyzed by a gas-liquid chromatograph and those for hydroquinone were analyzed by ultraviolet spectrophotometer. 
3 (cont') 75-84

D. Evaluation Criteria

The Occupational Health Standards relevant to this evaluation as promulgated by the U. S. Department of Labor (Federal Register, Volume 39, June 27, 1974, pages 23541 and 235421) are as follows:

Substances

Acetic Acid

Hydroquinone
8-Hour Time Weighted Average

$25 \mathrm{mg} / \mathrm{m}^{3}$

$2 \mathrm{mg} / \mathrm{m}^{3 *}$

* mg/m ${ }^{3}$ - denotes approximate miliigrams of substance per cubic meter of air.

E. Evaluation Results

Samples were collected for each contaminant in the employee's breathing zone and in the darkroom area with the ceiling exhaust fan and air conditioner operating.

The lower limits of detection for acetic acid and hydroquinone are less than 0.02 and $0.03 \mathrm{mg} / \mathrm{m}^{3}$ respectively. Both the personal and general air samples specifically collected for each contaminant did not reach these levels.

F. Discussions, Conclusions and Recommendations

During the environmental study on July 31, 1975, the measured outside temperature at $2 \mathrm{p} . \mathrm{m}$. was $900 \mathrm{~F}$. During this study, the operator did not complain of adverse health affects, whereas he did so during the initial visit. This may be due to the fact that the air conditioner was operating on the day of the evaluation while no air movement was noticeable during the initial visit.

Using smoke ventilation tubes, it was noted that the ceiling exhaust fan had a minimum of effectiveness in exhausting the contaminants. Utilizing an Alinor Jr. Velometer, the measured ventilation rate was 300 feet per minute at the grill. The rate dropped to 50 feet per minute, 6 inches from the grill and was not measureable at the source of the contaminant generation which was approximately 8 feet from the exhaust fan. Furthermore, if the exhaust system was effective, the contaminant would have been exhausted into the false ceiling area and not outdoors. 
4 (cont') 74-85

During the evaluation, it was noted that an automatic developing and drying machine was being installed. It was noted that this machine had a duct for an exhaust system. This duct was not connected and it would exhaust the contaminant into the work atmosphere. It is recommended that the duct be extended and the contaminant be exhausted outdoors in such a manner that it cannot reenter through open windorws.

$\mathrm{V}$ References

1. Federal Register, Vol. 39, No. 125, Part II, Subpart 6, June 27, 1974 .

VI Authorship and Acknowledgment

Report Prepared By:

Originating Office:

Laboratory Analysis:
Walter J. Chrostek

Industrial Hygienist

Region III

Jerome P. Flesch

Chief, Hazard Evaluation

Services Branch

Joseph Lebrizzi

Western Area Occupational Health Laboratory - NIOSH, Salt Lake City, UT 
INSTANT COPY SERVICE

Philadelphia, Pennsylvania

HEALTH HAZARD EVALUATION DETERMINATION

Report No. $74-85$

ACETIC ACID AIR CONCENTRATION DATA

July 31,1975

$\begin{array}{ccccc}\text { ample No. } & \begin{array}{c}\text { Time Duration } \\ \text { (minutes) }\end{array} & \begin{array}{c}\text { ir Volume } \\ \text { (L iters) }\end{array} & \begin{array}{c}\text { Concentration } \\ \mathrm{mg} / \mathrm{m}^{*}\end{array} & \text { Remarks } \\ 358 & 436 & 409 & \text { N. D. ** } & \begin{array}{c}\text { Operator's exposure General air, } \\ \text { Developing room }\end{array}\end{array}$

HYDROQUINONE AIR CONCENTRATION DATA

\begin{tabular}{|c|c|c|c|c|c|c|c|}
\hline $\begin{array}{l}87 \\
298\end{array}$ & $\begin{array}{l}436 \\
428\end{array}$ & $\begin{array}{l}409 \\
504\end{array}$ & $\begin{array}{l}\text { N. D. }{ }^{* * *} \\
\text { N. D. }\end{array}$ & $\begin{array}{l}\text { Operator's } \\
\text { Developing }\end{array}$ & $\begin{array}{l}\text { exposure } \\
\text { room }\end{array}$ & General & air, \\
\hline
\end{tabular}

*mg/m ${ }^{3}$ - denotes milligram of substance per cubic meter of air sampled.

* N.D. - none detected, lower level of detection $=0.03 \mathrm{mg} / \mathrm{m}^{3}$ for Acetic Acid

*** N.D. - none detectected, lower levei of detection $=0.02 \mathrm{mg} / \mathrm{m}^{3}$ for hydroquinone 